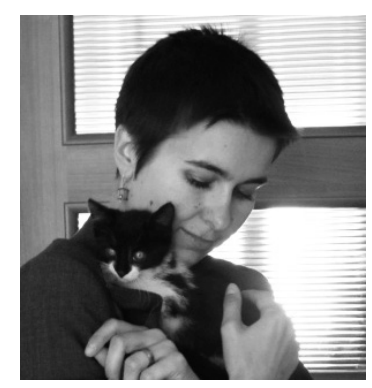

Magdalena Geraga

Magdalena Geraga - doktor nauk humanistycznych w zakresie literaturoznawstwa, magister filozofii, adiunkt w Stargardzkiej Szkole Wyższej Stargardinum. Miłośniczka fauny i flory, wegetarianka, była sportsmenka, mentalna góralka. Publikowała w czasopismach „Red", , Undegrunt”, „Teka”, ,Odra”, , Protokół Kulturalny”, ,Fabula”, ,Parnasik". Zainteresowania badawcze koncentrują się wokół zagadnień literaturoznawczych, filozoficznych i antropologicznych. Ważniejsze artykuły: Między solipsyzmem a egzystencjalizmem. O "Kosmosie" Witolda Gombrowicza; Kierkegaardowskie stadia przejścia w "Procesie" Franza Kafki; Subiekt-obiekt, czyli Gombrowiczowskie paradoksy rzeczywistości; Czas ukryty w Bogu. „Pieśń o moim Chrystusie" Romana Brandstaettera. 


\title{
Kim jest Czerwona Magda, czyli rozważania o jednym opowiadaniu Stefana Grabińskiego
}

\begin{abstract}
Bo dziwnym też stworzeniem była córka strażaka. Wysoka, wątła i blada, zwracała uwagę dużymi, czarnymi, wiecznie w przestrzeń zapatrzonymi oczyma i ruchami rąk, których nigdy opanować nie umiała. Ręce te, równie blade jak twarz, przebiegały ustawicznie jakieś nerwowe dreszcze czy skurcze, wywołując niespokojny, spazmatyczny ruch palców - długich, wąskich, wiecznie zimnych. Włosy miała bujne, czarne, które w lśniących kruczo wężach wymykały się spod jedwabnej, ognistopomarańczowej chusty, jedynej ozdoby, na jaką stać było biedną dziewczynę $[\mathrm{CM}, \mathrm{s.} \text { 171 }]^{1}$.
\end{abstract}

ak, Magda jest dziwna. Znerwicowana, budząca lęk u własnego ojca, cierpiąca na somnambulizm, piromanię, posiadająca właściwości nadprzyrodzone oraz skłonności destrukcyjne i autodestrukcyjne... Dziewczyna jest ponadto skazana na niedookreślenie i fatalizm zarówno poprzez swe pochodzenie - to córka strażaka i płomiennej Cyganki, która osierocając ją wcześnie, pozostawiła niejako w spadku „tęsknotę do wielkich, bezkresnych stepów" (CM, s. 171) - jak i przepowiednię starej Cyganki. Wieszczka kreuje życie Magdy, nazywając ją, jeszcze nienarodzoną, „,córką płomieni”, dodając, iż będzie zwalczana przez „człowieka białego, osiadłego”, tego, który ją spłodził, słowem: przez własnego ojca. Według Martina Bubera „dla człowieka myślącego magicznie «prawdziwe» imię osoby czy jakiegokolwiek przedmiotu nie jest wyłącznie określeniem; jest ono esencją osoby, poniekąd wydestylowaną z jej realności, wskutek czego istnieje ona w nim je s z c z e j a k b y r a z"2. Tajemnicze słowa Cyganki zaczynają nabierać realnego, acz przerażającego znaczenia, kiedy Magda kończy piętnaście lat, w momencie dojrzewania, „pomiędzy” stanem dzieciństwa a dojrzałością - wtedy to mają miejsce pierwsze tajemnicze podpalenia.

\footnotetext{
1 Artykuł oparty na edycji noweli Czerwona Magda z roku 1975 (NO). Cytaty zlokalizowano w tekście, opatrując je skrótem CM wraz z numerem strony w nawiasie.

2 Za: J. Tokarska-Bakir, Obraz osobliwy. Hermeneutyczna lektura źródeł etnograficznych. Wielkie opowieści, Kraków 2000, s. 370-371.
} 


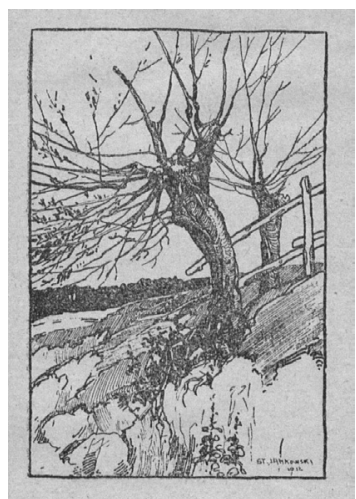

Ilustracja do dramatu Ciemne sity (Willa nad morzem), Przemyśl 1921, rys. S. Jankowski
Życie dziewczyny, całkowicie podporządkowane sile ognia, staje się niejako metaforą żywiołu, który - według ludowych przekazów - odczuwa emocje i odpowiada na zachowania ludzi: złości się zatem, kiedy się go gasi, irytuje, kiedy jest pożyczany, mści za nieuszanowanie ${ }^{3}$. Ogień to „ja”, moja tożsamość, a zarazem nietożsamość, rozdarcie na siebie i nie-siebie, zmiana, stawanie się, ciągły ruch i zaprzeczanie sobie, przemijanie. „Płomienne” życie nie daje się objąć żadną logiką i wiedzą, jest egzystencją ukrytą, chowającą się pod światłem zjawisk. Ogień żyje wiecznie, czyniąc tak zło (pożar), jak i dobro (ciepło życiowe) ${ }^{4}$ : Czerwona Magda jest przeto zwalczana przez ojca, wzbudza w nim jednocześnie troskę i czułość. „Ogniste” cechy, które posiada dziewczyna - nieokreśloność, niejednoznaczność, mediumiczność, zdolność do transgresji i, co najistotniejsze, do wytwarzania ognia - predestynują ją do kontaktu z sacrum, niepodlegającemu ani ludzkim prawom, ani ludzkiej moralności ${ }^{5}$. Dziewczyna znajduje się w pobliżu nienazwanego bóstwa, którego epifanią jest ogień, a więc - w pewnym sensie - ona sama.

W doświadczeniu religijnym, które staje się udziałem dziewczyny, można odnaleźć elementy zarówno racjonalne (piromania), jak i nieracjonalne - najbardziej istotna część owego doświadczenia wymyka się intelektualnemu poznaniu. Według Rudolfa Otto objawienie świętości jest dostępne jedynie wybranym, dostrzeżenie i przyjęcie epifanii to dar ${ }^{6}$. Zdaje się jednak, że ów wątpliwy dar w wypadku Magdy zamienia się zarówno dla niej, jak i dla tych, z którymi ma do czynienia, w przekleństwo. Czerwona Magda jest zarażona fatalizmem; w samotności musi zmagać się z niezrozumieniem i potępieniem swego przeznaczenia.

Autor Świętości usiłuje wykazać, że świat nadprzyrodzony wychodzi naprzeciw poprzez zjawiska, których nie da się wyjaśnić racjonalnie. Ważna jest intuicja przenosząca dane zmysłowe do rzeczywistości pojęciowej. Nie byłoby to możliwe, gdyby nie przeczucie, iż istnieje świat wyższych wartości. Według badacza religia koncentruje się wokół trzech podstawowych pojęć: numinosum, świętości apriorycznej i irracjonalizmu religijnego. Skupmy się na numinosum: to siła, która ma ogromny wpływ na człowieka, zarówno pociąga, jak i napawa przerażeniem. Czy nie tak jest w wypadku „córki płomieni”? Niepokój, który wzbudza Magda, jest związany nie tylko z jej uczynkami, ale i tajemnicą, niemożnością dojścia do „niej samej”, do duszy, umysłu, intencji dziewczyny. Oto jakie uczucia wzbudza dziewczyna we własnym ojcu: „Ojciec kochał Magdę uczuciem tkliwym i serdecznym, lecz jakby z odcieniem lęku przed własnym dzieckiem. Piotr Szponar bał się swej córki. Bał się jej białej jak marmur twarzy, jej wąskich, zaciętych uporczywie ust, jej długich a częstych zamyśleń” (CM, s. 171). Numinosum, na co należy zwrócić uwagę, jest kategorią religijną sensu stricto, niezależną od innych dziedzin kultury, a także usytuowaną poza moralnością. Wobec niego człowiek czuje swą ontyczną wtórność; wie, iż jest „pyłem”, „prochem”, „nicością”. Numinosum może aprobować zarówno czyny powszechnie uznawane za moralne, jak i okrutne. Wymaga więc ofiar z ludzi, nie licząc się z etyką. Stając się kapłanką ognia, a jednocześnie służką numinosum, Magda - oddalając się od sfery aksjologicznej - składa z domostw oraz spopielonych mieszkańców ofiarę swemu bogu?

3 Słownik stereotypów i symboli ludowych, red. J. Bartmiński, t. 1, Kosmos, cz. 1, Lublin 1996, s. 268.

${ }^{4}$ Zob. K. Michalski, Płomień wieczności, cz. 2, "Znak” 2004, nr 2.

${ }^{5}$ P. Kowalski, Ogień, [hasło w:] idem, Kultura magiczna. Omen, przesqad, znaczenie, Warszawa 2007, s. 372; K. Moszyński, Kultura ludowa Słowian, t. 2, Kultura duchowa, cz. 1, Warszawa 1967, s. 263.

${ }^{6}$ R. Otto, Świętość. Elementy racjonalne i irracjonalne w pojęciu bóstwa, tłum. B. Kupis, Wrocław 1993, s. 40.

7 Zob.: „Kapłan zamieni to w dym na ołtarzu jako pokarm, jako ofiarę spalaną dla Pana” (Kpł 3,11), Pismo Święte Starego i Nowego Testamentu, red. A. Jankowski et al., tłum. Cz. Jakubiec, Poznań 2009. Umiejętność 
Stetan Gratricki.

- Prryadele.

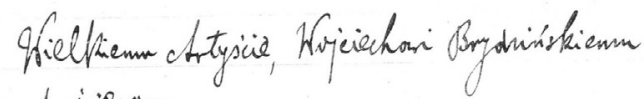
frinizearm.
Autograf noweli

Przypadek, k. 1-2.

Ze zbiorów Biblioteki

Uniwersytetu Łódzkiego

(BUL)

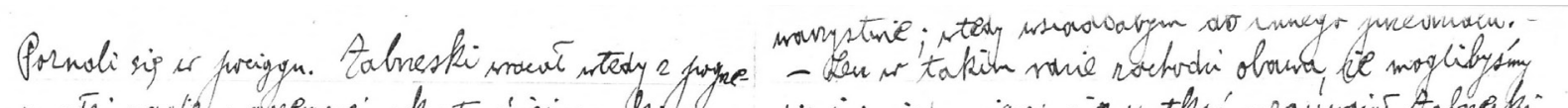

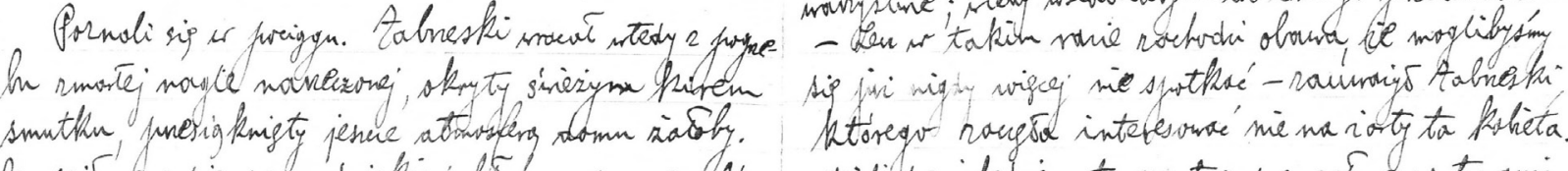

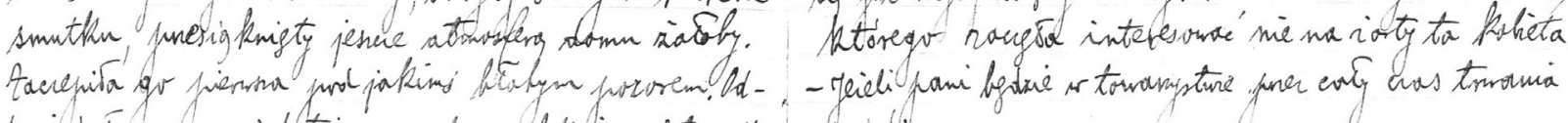

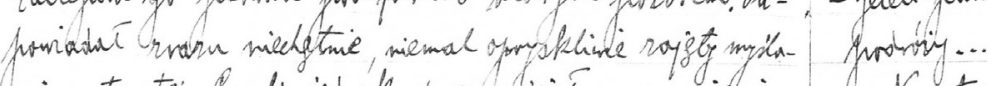

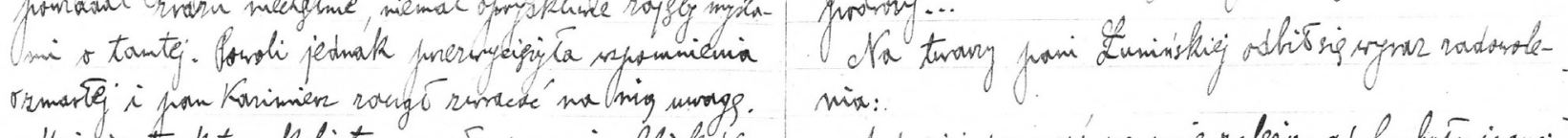

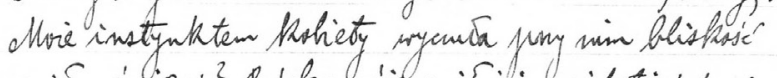

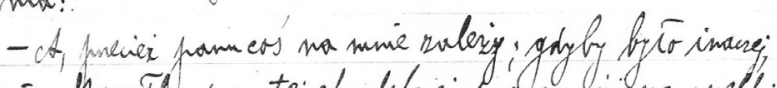

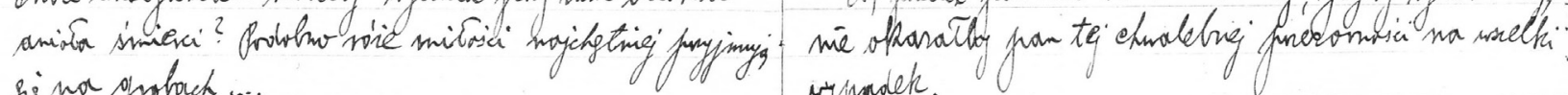
sig no grobloch....

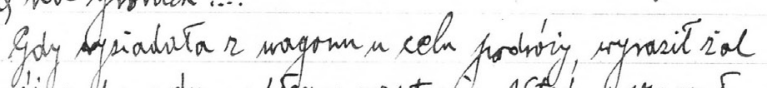
wypadek.

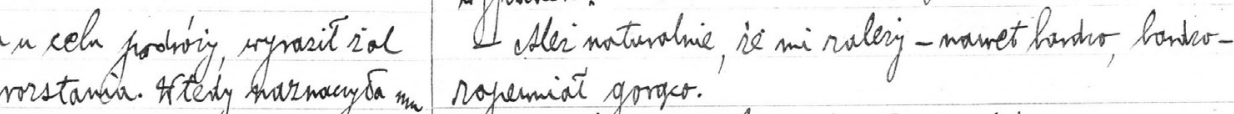
Aienorng schood kg w horiggu. Gienrng schowhkg wo horiggu.

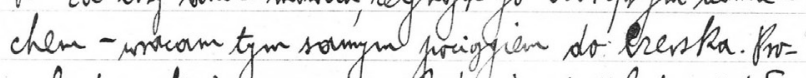

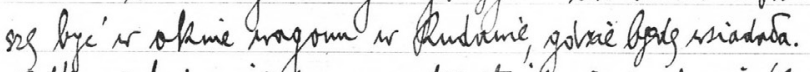
nol dris' ra ouna tognosine.

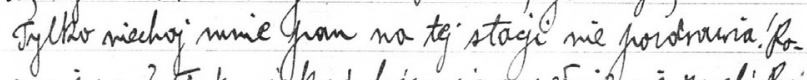
- ctle gduie?

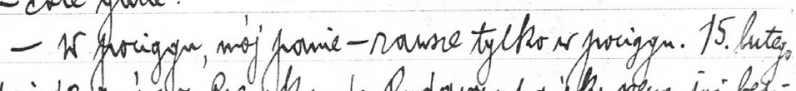

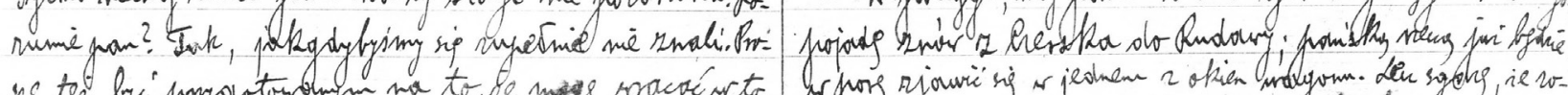

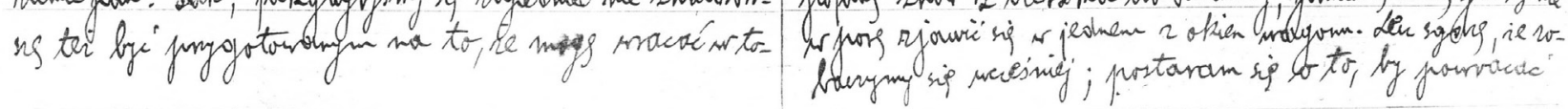

LC_11.indb 197

2013-06-21 08:34:14 
Dziewczyna poprzez swą ontologiczną i epistemologiczną niejednoznaczność ma wszelkie zadatki ku temu, aby nadać jej status obcego, który wzbudza zarówno przerażenie, jak i fascynację. I ów status jest jej rzeczywiście nadany: „odtąd Szponarówna, przezwana Czerwoną Magdą, uchodziła za podpalaczkę i czarownicę, której wszyscy schodzili z drogi, bojąc się przepuścić ją na próg swego domu" (CM, s. 173). Dziewczyna jest nie tylko obca dla innych, staje się niejako elementem nieoswojonym dla samej siebie. Niezwykłe rzeczy będące jej udziałem dotykają ją w stanie somnambulicznego transu, nad którym nie ma władzy. Uwalniając świat i podpalane przedmioty od ich zewnętrznej, materialnej postaci, odurzając się dymem, bezkształtnym i efemerycznym, traktowanym jako metonimia zaświatów ${ }^{8}$, Magda wpada w trans oddalający ją od społeczności ludzkiej, trans graniczący z szaleństwem. Obłąkanie Magdy jest zresztą potwierdzone przez żywo zainteresowanych sprawą ewentualnej piromanii medyków: uznają ją oni za „istotę anormalną, z przewagą sił podświadomych, skłonną do katalepsji, a nawet somnambulizmu" (CM, s. 173).

Niepokój, jaki wzbudza obłąkany, jest związany z chaosem cechującym szaleńca, z tym, że nie respektuje on praw rzeczywistości ${ }^{9}$. Jego niestabilność zaprzecza temu, co człowiek buduje z takim pietyzmem wokól siebie. Magda przeraża nawet samego ojca, który czuje się za nią odpowiedzialny, jednocześnie - z racji wykonywanego zawodu - odpowiedzialny także za tych, których Magda chcąc nie chcąc (?) krzywdzi.

Szaleństwo staje się najczęściej udziałem osoby mającej wcześniej kontakt z osobami demonicznymi, obcymi; w wypadku Magdy może to być spotkanie z Cyganką wróżbiarką, która jest w pewnym sensie postacią „nie z tego świata”. Sam obłąkany bywa niekiedy traktowany jako opętany, wymagający odczynienia egzorcyzmów. Magdzie jest to darowane; przypisuje się jej - szalonej i innej - „jedynie” status kozła ofiarnego ${ }^{10}$ :

Wreszcie ni stąd, ni zowąd, po okrutnym pożarze na Lewandówce, który spalił niemal doszczętnie świeżo wystawioną kamienicę miejskiego syndyka, gruchnęła nagle pogłoska, że sprawczynią tylu klęsk nie jest nikt inny tylko Magda Szponarówna, służąca w domu Doleżanów. Wzburzony tłum pospólstwa napadł na nią na środku rynku i byłby przeprowadził nad nieszczęśliwą doraźną egzekucję, gdyby nie interwencja ojca, powszechnie lubianego i cenionego obrońcy dobra publicznego, oraz policji, która uprowadziła dziewczynę przed zemstą rozwścieczonego motłochu [CM, s. 172].

Magda unika linczu, jednak wyrzuca się ją - za pośrednictwem ojca - poza granice miasta, wyklucza ze społeczeństwa, zrzucając winy za wszelkie zło, które zostało dokonane. Dziewczyna gaśnie poza granicami swojego świata, poza sferą mocy strażaka stanowiącego centrum jej życia, swoiste, gdyż ruchome, axis mundi ${ }^{11}$ - jest bledsza, chudsza, jeszcze bardziej zamknięta w sobie. Przywrócona - po dwóch latach - do oswojonej przestrzeni, dochodzi do siebie, reaktywując czynienie szkód. Jej siła, ale i obłąkanie, jest spotęgowane w pobliżu

wytwarzania ognia jest w wielu kulturach traktowana jako zdolność przyszłego kapłana do przekraczania samego siebie, zob. H. Biegeleisen, Lecznictwo ludu polskiego, Kraków 1929, s. 303.

8 P. Kowalski, Dym, [hasło w:] idem, Kultura magiczna, s. 107.

${ }_{9}^{9}$ K. Moszyński, op. cit., s. 97-99.

10 Zob. R. Girard, Koziołofiarny, tłum. M. Goszczyńska, Łódź 1991.

11 Zob. M. Eliade, Traktat o historii religii, tłum. J. Wierusz-Kowalski, Warszawa 2000, s. 396-400. 


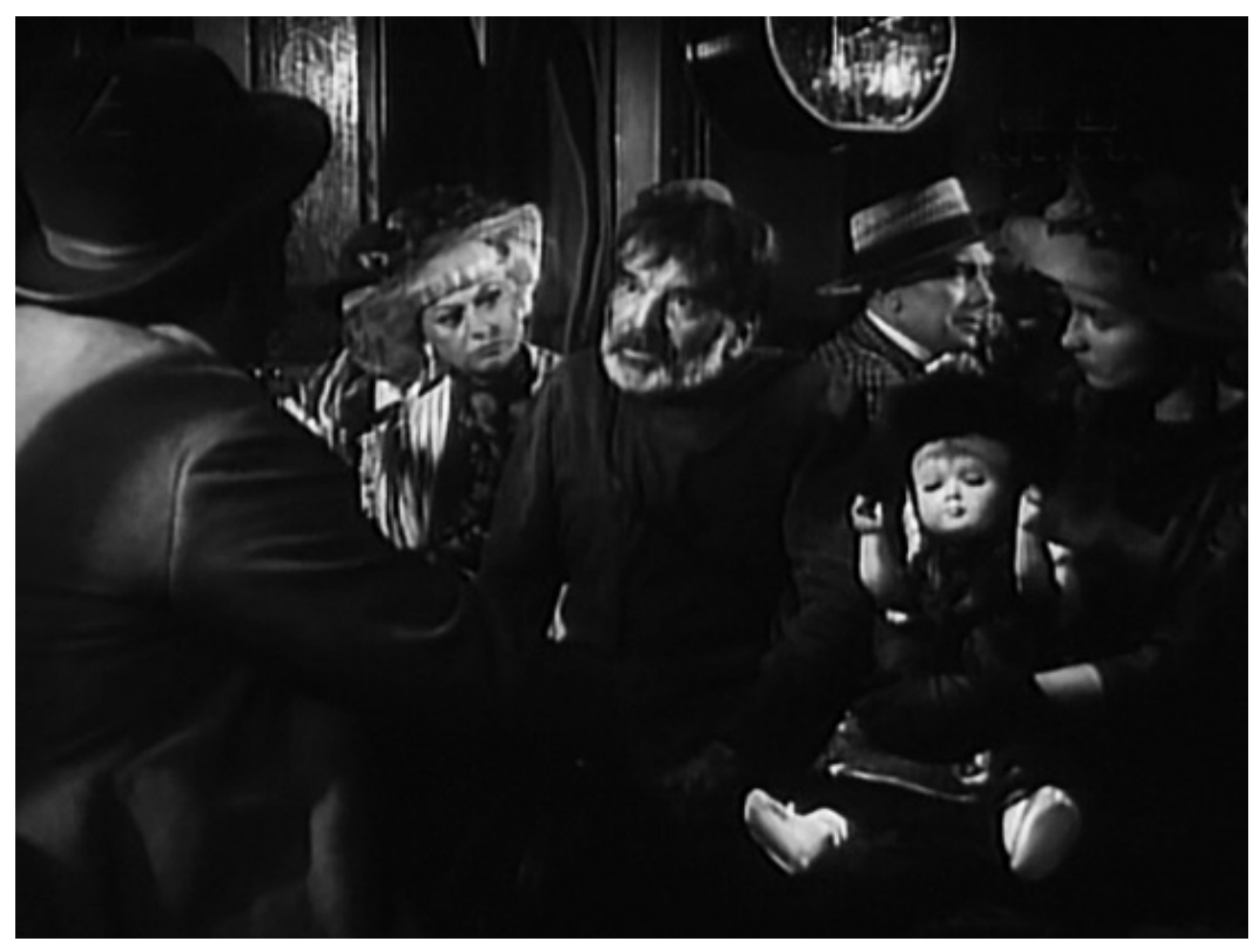

Kadr z filmu Ślepy tor,

reż. Ryszard Ber, 1967

centrum, czyli ojca. Punkt centralny jest miejscem inicjującym wszelkie istnienie - strażak dał początek Magdzie, jest też miejscem finalnym - dziewczyna umiera z rąk ojca ${ }^{12}$.

Axis mundi to miejsce hierofaniczne (ujawnia się tu świętość), ale to także płaszczyzna mediacji, niekiedy nieuprawnionej, przynoszącej cierpienie ${ }^{13}$. To w pobliżu strażaka Magda czyni zło. Magda i jej ojciec, zespoleni nie tylko więzami krwi, ale i naznaczeni fatalizmem, tworzą wspólnotę ognia - formę więzi hermetycznej - stanowiącą strukturę, do której nie byli dopuszczani obcy, czyli członkowie innego rodu. Ogień płonął w domostwie, był świętością ${ }^{14}$, tak ważnym elementem w życiu rodziny, iż podlegał podziałowi w trakcie jej rozbicia. Nieobecność ojca powoduje „gaśnięcie” Magdy. Stary Szponar, wbrew rozsądkowi, doprowadza do powrotu córki - bez niej zdaje się niepełny. Strażak zresztą czuje się współodpowiedzialny za „ogniste” wydarzenia: „Czasami przychodziła myśl, że może właśnie dlatego, może właśnie za tę zaciętość, z jaką zwalczał ogień, przyszedł nań dopust; może okrutny żywioł mścił się na nim w ten sposób” (CM, s. 174). To w pobliżu strażaka Czerwona Magda otwiera się na sferę sacrum, doznając rytualnej śmierci (dziewczyna mdleje, doznaje stanów somnambulicznych, transgresywnych), swoistej dezorganizacji siebie - przekracza swoją ludzką naturę, stając się postacią graniczną.

\footnotetext{
${ }^{12}$ P. Kowalski, Centrum, [hasło w:] idem, Kultura magiczna, s. 48.

13 Ibidem, s. 47.

14 A. Anisimov, Wierzenia ludów Północy, tłum. A. Wierzchowska, Warszawa 1971, s. 197.
} 
Na granicy mieli czekać na odmianę losu ludzie zaklęci, hybrydyczni i zaczarowani ${ }^{15}$, mogą się tu dziać różne rzeczy, pojawiać niesamowitości. Na granicy inicjowano działania magiczne, a także dokonywało się wtajemniczanie w zło, $w$ działania szkodzące innym ${ }^{16}$. Ta sfera wymyka się wszelkim definicjom, jest dwuznaczna, nie należy do żadnej konkretnej części świata. Tak jak Magda: „Gdyby go [Szponara] spytano na spowiedzi: - Sierżancie pożarny, Piotrze Szponar - czy córka twoja jest winną? Odpowiedziałby, że nie, o ile chodzi o jej własne sumienie i pełną ludzką świadomość. Lecz gdyby go ktoś zapytał, czy wierzy w bezwzględną niewinność Magdy, zaprzeczyłby równie stanowczo” (CM, s. 174). Magda oscyluje pomiędzy sferą kultury, pracując jako służąca - do czego notabene bardzo się przykłada - a natury, poddając się drzemiącym w niej fatalistycznym skłonnościom. W tym znaczeniu przekracza granicę horyzontalną. $\mathrm{Z}$ drugiej strony dym, który przynosi ze sobą dziewczyna, jest niejako próbą przejścia granicy wertykalnej; nienależąca do tego świata Magda wznosi się ku bliżej niezdefiniowanym niebiosom (choć jej destrukcyjna natura oraz czynione zło powinny raczej kierować ją ku wiadomemu dołowi).

W pewnym momencie Magda przechodzi niezwykle wyraźną przemianę, staje się upiorem, istotą nie z tego świata. Według podań ludowych wampiry (upiory) odznaczają się wysokim wzrostem, dzikim wzrokiem i nadludzką siłą. Skutecznym sposobem walki z nimi jest m.in. żelazny nóź ${ }^{17}$. Magda zostaje zabita przez jedynego człowieka, który mógł dokonać tego czynu: przez swego ojca. Strażak, uczyniwszy przedtem znak krzyża, unicestwia Magdę upiora za pomocą strażackiego emblematu: toporka. W tym momencie Magda przekracza ostatnią w życiu granicę: pomiędzy bytem a nie-bytem.

„Córka płomieni”, kapłanka żywiołu, nie ginie w ogniu; jeśli wierzyć Gastonowi Bachelardowi, taka śmierć byłaby końcem najmniej samotnym, oznaczałaby bowiem śmierć kosmiczną. Śmierć totalna, idealne ciałopalenie jest bowiem świadectwem roztopienia się $\mathrm{w}$ żywiole, a co za tym idzie roztopienia się $\mathrm{w}$ nicości ${ }^{18}$.

Tej, która bez ognia żyć nie może, świat - niejako za karę - zgotował inny koniec: śmierć samotną, podkreślającą jej inność, obcość, szaleństwo. Opowiadanie kończy się wraz z agonią dziewczyny, nie wiemy zatem, czy prawdą jest, że „obłąkanie na ziemi oznacza szczęście w niebiosach" ${ }^{\prime \prime}$. Nie wiadomo też, jakie są dalsze losy strażaka. Czy jego życie, tak podporządkowane roli, jaką odegrał w życiu Magdy i miasteczka, jest misją, która wypełniła się wraz ze śmiercią „córki płomieni”, i czy czeka go teraz inna rola społeczna, mniej chlubna, acz też ważna? „Odwrócenie się agresywności w obrębie pewnej specyficznej grupy i jej skierowanie ku czemuś zewnętrznemu w stosunku do grupy (albo też ku czemuś będącemu jej częścią, ale odrzuconemu przez grupę), sprawia, że dana grupa czy para nabiera silnej spoistości” - twierdzi René Girard ${ }^{20}$. Permanentna walka, która określała starego strażaka, zastąpiona została bezsilnością, załamaniem, a także „biczem spojrzeń” zgromadzonego tłumu. Ci, którzy jeszcze przed chwilą traktowali Szponara jak bohatera, stają się częścią „długiego, męczącego szpaleru”, wykluczając niewygodny element ze swej wspólnoty.

Magda nie żyje, czas znaleźć nowego kozła ofiarnego.

\footnotetext{
15 L. Stomma, Antropologia kultury wsi polskiej XIX W., Warszawa 1986, s. 163.

16 J. Kowalska, Taniec drzewa życia. Uniwersalia kulturowe w tańcu, Warszawa 1991, s. 134.

17 B. Baranowski, W kręgu upiorów i wilkołaków, Łódź 1981, s. 61, 72-73; L. J. Pełka, Polska demonologia ludowa, Warszawa 1987, s. 155.

${ }^{18}$ G. Bachelard, Wyobraźnia poetycka, tłum. H. Chudak, A. Tatarkiewicz, Warszawa 1975, s. 35.

${ }^{19}$ K. Moszyński, op. cit., s. 195.

20 R. Girard, Poczq̨tki kultury, tłum. M. Romanek, Kraków 2006, s. 148.
} 


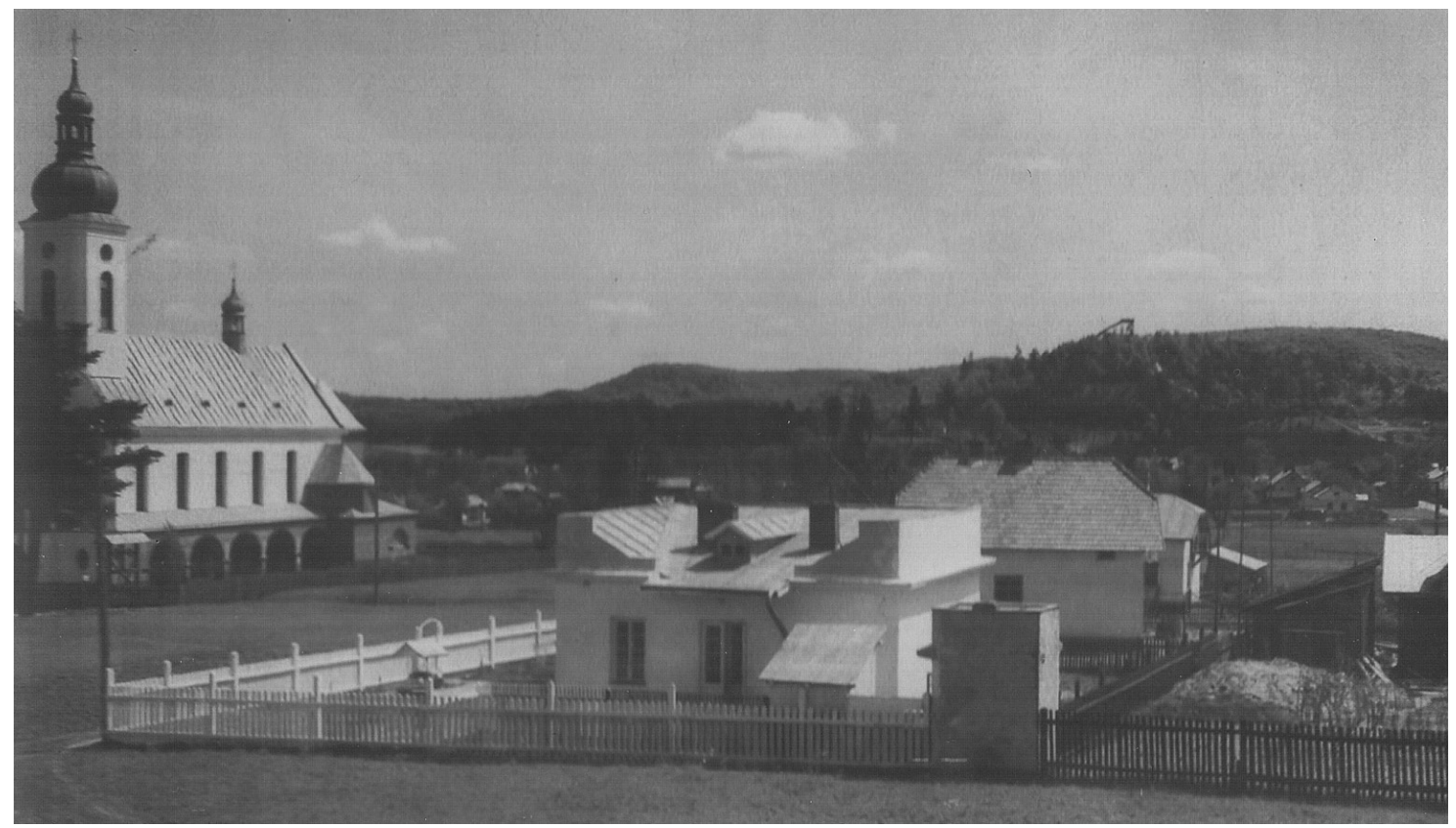

Brzuchowice pod Lwowem, miejsce pobytu pisarza w I. 1930-1934. Archiwum Adriana Mianeckiego

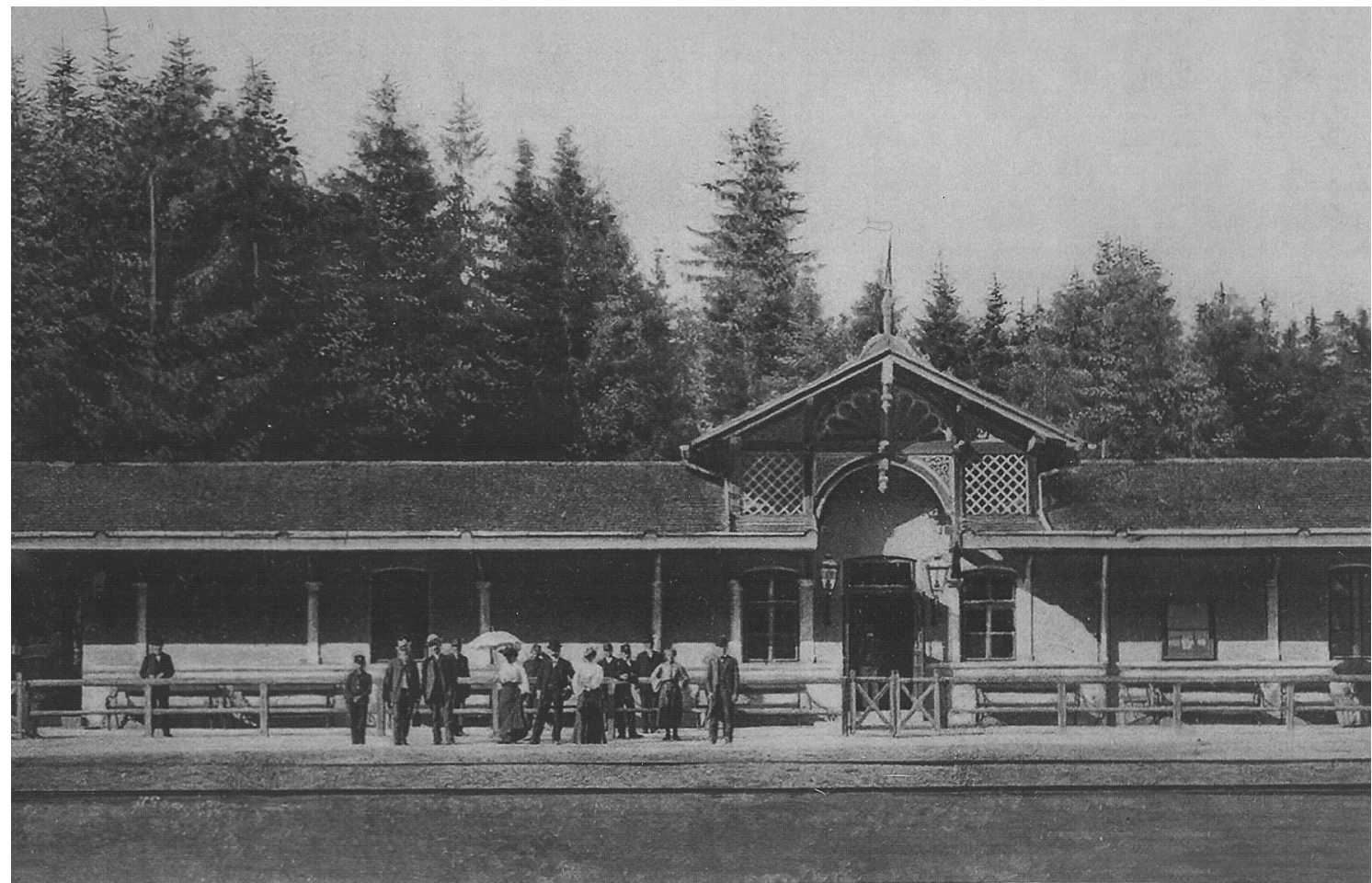

Brzuchowice, dworzec kolejowy. Archiwum Adriana Mianeckiego 